\title{
DETERMINAN-DETERMINAN MANAJEMEN LABA PADA PENAWARAN SAHAM PERDANA (KASUS PADA PERUSAHAAN SEKTOR ANEKA INDUSTRI) $\left.{ }^{1}\right]$
}

\author{
Tatang Ary Gumanti \\ Sheila Regina Prihandini \\ Elok Sri Utami \\ Jurusan Manajemen, Fakultas Ekonomi, Universitas Jember \\ tatangag@yahoo.com; sheilareginaprihandini@yahoo.com
}

\begin{abstract}
This study analyzes the effect of operating cash flow, earnings changes, leverage, and the intended use of the IPO proceeds on earnings management of companies in various industry sector making initial public offerings (IPOs) in Indonesian stock exchange. The samples of this study were selected using purposive sampling method in which there were 15 out of 33 companies in the period 1990-2012. The data used are secondary data from a variety of industry sectors. The company's prospectuses are obtained from the database of the Faculty of Economics, University of Jember, Indonesian Capital Market Directory (ICMD), and other sources. The dependent variable in this study is earnings management measured using the ratio of Discretionary Accruals developed by Friedlan (1994). Independent variables consist of operating cash flow, earnings changes, the intended use of IPO proceeds measured as dummy variables, and leverage ratio measured as debt to equity ratio. The results showed that only operating cash flow has significant negative effect on earnings management. The change of earnings, leverage, and the intended use of IPO funds do not affect significantly the company's earnings management in various industry sector.
\end{abstract}

Keywords: earnings management, operating cash flows, changes in earnings, leverage

\begin{abstract}
Abstrak
Penelitian ini menganalisis pengaruh arus kas operasi, perubahan laba, leverage, dan tujuan penggunaan dana hasil IPO pada manajemen laba perusahaan di berbagai sektor industri yang melakukukan penawaran saham perdana (IPO) di Bursa Efek Indonesia. Sampel penelitian ini dipilih dengan menggunakan metode purposive sampling di mana ada 15 dari 33 perusahaan pada periode 1990-2012. Data yang digunakan adalah data sekunder dari berbagai sektor industri. Prospektus perusahaan diperoleh dari database Fakultas Ekonomi, Universitas Jember, Direktori Pasar Modal Indonesia (ICMD), dan sumber-sumber lainnya. Variabel terikat dalam penelitian ini adalah manajemen laba, yang diukur dengan menggunakan rasio Discretionary Akrual yang dikembangkan oleh Friedlan (1994). Variabel independen terdiri dari arus kas operasi, perubahan laba, tujuan penggunaan dana IPO yang berfungsi sebagai variabel dummy, dan rasio leverage diukur dengan rasio hutang terhadap ekuitas. Hasil penelitian menunjukkan bahwa hanya arus kas operasi yang berpengaruh negatif dan signifikan terhadap manajemen laba. Sementara perubahan pendapatan, leverage, dan tujuan penggunaan dana IPO tidak mempengaruhi secara signifikan manajemen laba perusahaan di berbagai sektor industri.
\end{abstract}

Kata kunci: manajemen laba, arus kas operasi, perubahan laba, leverage

\footnotetext{
${ }^{1}$ Penulis mengucapkan terimakasih atas masukan dari reviewer dan peserta Forum Manajemen Indonesi (FMI) ke-6 di Medan tahun 2014, Sumatera Utara
} 


\section{PENDAHULUAN}

Initial Public Offering (IPO) merupakan peristiwa dimana untuk pertama kalinya suatu perusahaan menjual sahamnya kepada khalayak ramai (public). Pada umumnya dalam menetapkan harga penawaran suatu perusahaan untuk pertama kalinya kepublik merupakan hal yang tidak mudah. Ketepatan dalam menentukan harga penawaran perdana sangat memengaruhi kesejahteraan pemilik lama (issuers). Pemilik lama (issuers) tentu mengharapkan harga jual yang tinggi, karena dengan harga jual yang tinggi penerimaan dari hasil penawaran akan tinggi pula. Hal ini menunjukkan bahwa tingkat kesejahteraan mereka juga akan semakin baik. Dilain pihak bagi investor, harga yang tinggi dapat memengaruhi minat untuk membeli atau memesan saham yang ditawarkan. Harga terlalu tinggi akan menyebabkan minat investor rendah, sehingga besar kemungkinan saham yang ditawarkan akan kurang laku. Ini semua disebabkan karena tidak adanya informasi harga yang relevan dalam penetapan harga jual di pasar perdana, selain itu keterbatasan informasi tentang perusahaan yang go public tersebut membuat calon investor harus melakukan analisis yang menyeluruh sebelum mengambil keputusan untuk membeli saham.

Salah satu sumber informasi yang relevan untuk digunakan dalam menilai perusahaan yang akan go public adalah laporan keuangan yang terdapat di dalam prospektus (Nastiti dan Gumanti, 2011). Di dalam prospektus, investor mendapatkan sumber informasi tentang perusahaan yang paling lengkap karena sebagian besar isi prospektus adalah laporan keuangan dan secara teoritis informasi keuangan merupakan salah satu sumber utama dalam proses penentuan harga saham saat IPO (Buck, 1990).

Adanya keterkaitan antara informasi laporan keuangan dalam prospektus dan IPO, mengharuskan calon investor dan investor untuk melihat kualitas laporan keuangan suatu perusahaan dengan melihat tingkat laba perusahaan yang bersangkutan. Laba yang dilaporkan oleh perusahaan merupakan petunjuk bagi calon investor dan investor untuk memprediksi mengenai ramalan laba perusahaan dimasa yang akan datang.

Rahman (2008) menyatakan bahwa laporan keuangan menjadi sumber informasi utama untuk menarik minat investor, maka perusahaan yang akan melakukan penawaran saham perdana diduga cenderung membuat laporan keuangan semenarik mungkin untuk memaksimalkan perolehan dana ketika melakukan IPO. Salah satu cara yang bisa dilakukan perusahaan yaitu melalui praktik manajemen laba sehingga terlihat bahwa laba perusahaan bukan mencerminkan laba yang sebenarnya. Niagara dan Gumanti (2007) menyatakan bahwa salah satu hal yang mendorong manajemen untuk melakukan manajemen laba pada saat IPO adalah adanya keraguan bahwa saham yang akan ditawarkan tidak direspon dengan baik oleh pasar jika laba yang dicatatkan perusahaan pada periode sebelum go public tidak menarik.

Scott (1997) berpendapat bahwa manajemen laba adalah tindakan manajemen untuk memilih kebijakan akuntansi dari suatu standar tertentu dengan tujuan memaksimalkan kesejahteraan nilai pasar perusahaan. Manajemen laba sering diartikan sebagai suatu proses yang dilakukan dengan sengaja. Manajemen laba dapat mengurangi kredibilitas laporan keuangan apabila digunakan untuk pengambilan keputusan, karena manajemen laba merupakan suatu bentuk manipulasi atas laporan keuangan yang menjadi sasaran komunikasi antara manajer dan pihak eksternal perusahaan (Surifah, 1999).

Jadi, manajemen laba merupakan tindakan seorang manajer untuk meningkatkan atau mengurangi laba yang dilaporkan saat ini dengan tujuan untuk memaksimalkan nilai perusahaan. Manajer melakukan praktik manajemen laba dengan mengatur komponenkomponen discretionary accruals. Konsep discretionary accruals memberi pengertian bahwa pihak manajemen dapat memanipulasi pendapatan akrual dan biasanya digunakan untuk mencapai pendapatan yang diinginkan.

Objek penelitian ini adalah perusahaan sektor aneka industri. Produk-produk dalam sektor aneka industri antara lain terdiri atas produk otomotif dan komponennya, produk tekstil dan garmen, produk industri alas kaki, kabel dan produk elektronik. Perbedaan produk yang dihasilkan akan menyebabkan tren penjualan yang berbeda, namun terdapat kesamaaan bahwa perusahaan sektor aneka industri sangat terpengaruh oleh kondisi perekonomian, karena produk yang dihasilkan 
berupa barang yang umur pemakaiannya dapat bertahan lama, misalnya kendaraan, produk tekstil, alas kaki, dan produk elektronik.

Sektor aneka industri dipilih karena sektor aneka indutri mampu berkembang dengan baik. Sektor tersebut terkena dampak dari krisis keuangan global yang terjadi pada tahun 2008 namun dapat bangkit kembali pada tahun 2010 yang dibuktikan dengan peringkat kedua tertinggi dalam mendukung kenaikan Indeks Harga Saham Gabungan (IHSG) yaitu sebesar 32,22\% (berita.liputan6.com, 5 Desember 2011) dan pada tahun 2011 kinerja keuangan sektor aneka industri mengalami pertumbuhan tertinggi dari seluruh sektor sebesar 12,34\% (indonesiafinancetoday.com).

Berpijak pada uraian di atas, tujuan penelitian ini adalah untuk menganalisis pengaruh arus kas operasi, perubahan laba, leverage, dan tujuan penggunaan dana IPO terhadap manajemen laba pada perusahaan sektor industri yang melakukan penawaran umum perdana (IPO) di Bursa Efek Indonesia (BEI). Hasil penelitian menunjukkan bahwa hanya arus kas dari aktivitas operasi yang berpengaruh signifikan terhadap manajemen laba. Sedangkan, perubahan, leverage, dan tujuan penggunaan dana tidak berpengaruh signifikan terhadap besar kecilnya manajemen laba pada perusahaan aneka industri yang melakukan IPO tahun 1990-2002.

\section{KAJIAN PUSTAKA}

\section{Manajemen Laba dan Penawaran Saham Perdana}

Manajemen laba (earnings management) mempunyai banyak definisi walaupun menggunakan terminologi yang berbeda namun definisidefinisi itu mempunyai pengertian yang serupa. Dalam arti sempit, manajemen laba didefinisikan sebagai perilaku manajer untuk mengatur besaran komponen discretionary accruals dalam menentukan besarnya besar kecilnya earnings. Sedangkan dalam arti luas, manajemen laba merupakan tindakan manajer untuk meningkatkan (mengurangi) laba yang dilaporkan saat ini atas suatu unit dimana manajer bertanggung jawab, tanpa mengakibatkan peningkatan (penurunan) profitabilitas ekonomis jangka panjang unit tersebut.

Healy and Wahlen (1999) mendefinisikan manajemen laba sebagai upaya manajemen dalam menggunakan pertimbangannya (judgement) dalam menyusun laporan keuangan sehingga dapat menyesatkan pemangku kepentingan (stakeholders) dalam menilai kinerja perusahaan atau dapat memengaruhi kontrakkontrak pendapatan yang telah ditetapkan berdasarkan angka-angka laporan keuangan. Nastiti dan Gumanti (2011) menunjukkan bahwa manajemen laba merupakan suatu cara bagi manajemen untuk melakukan intervensi dalam penentuan laba perusahaan. Manajemen laba biasa dilakukan untuk tujuan pribadi manajemen".

Jadi dapat disimpulkan bahwa manajemen laba merupakan tindakan curang yang dilakukan oleh manajemen dengan merubah isi laporan keuangan baik dengan mempermainkan besar kecilnya maupun menyembunyikan atau menunda pengungkapan komponen tertentu, semua ini dilakukan untuk mengelabuhi investor, dengan tujuan memaksimalkan kesejahteraan perusahaan.

Dalam konteks IPO, penelitian tentang faktor-faktor yang berpengaruh terhadap manajemen laba sudah banyak dilakukan. Misalnya, Hamzah (2009) menunjukkan bahwa arus kas operasi berpengaruh negatif dan signifikan terhadap manajemen laba pada peristiwa IPO. Aussenegg et al. (2009) menemukan bukti bahwa arus kas operasi mampu membatasi manajemen laba pada 4.745 perusahaan sampel di Eropa periode 19952005. Nastiti dan Gumanti (2011) yang juga menunjukkan bahwa arus kas operasi berhubungan negatif dan signifikan dengan manajemen laba. Berdasarkan penelitian terdahulu mengenai perubahan laba maka dapat dinyatakan hipotesis pertama pada penelitian ini adalah arus kas operasi berpengaruh negatif terhadap manajemen laba pada perusahaan sektor aneka industri yang melakukan IPO di BEI. Sementara itu, Hsu dan Wen (2015) melaporkan bahwa dua tahun dan tiga tahun setelah IPO, perusahaan di Taiwan masih melakukan manajemen laba.

Burgstahler and Dichev (1997) meneliti perusahaan di Amerika Serikat menyimpulkan bahwa manajer berusaha menghindari penurunan laba dan menghindari kerugian dengan melakukan manajemen laba. Oleh sebab itu, perubahan laba dapat dijadikan sebagai salah satu indikasi terjadinya manajemen laba. Penelitian Nastiti dan Gumanti (2011) juga 
menunjukkan bahwa perubahan laba berhubungan positif tetapi tidak signifikan dengan praktik manajemen laba. Berdasarkan penelitian terdahulu maka dapat dinyatakan hipotesis kedua yaitu perubahan laba berpengaruh negatif terhadap manajemen laba pada perusahaan sektor aneka industri yang melakukan IPO di BEI.

Variabel lain yang sering dikaitkan dengan manajemen laba adalah leverage. Widyaningdyah (2001) menemukan leverage berpengaruh signifikan terhadap manajemen laba. Hal ini sejalan dengan penelitian yang dilakukan De Found and Jimbalvo (1994) dan Sanjaya (2008), yang membuktikan bahwa perusahaan dengan tingkat leverege tinggi cenderung melakukan manajemen laba dibandingkan dengan perusahaan dengan tingkat leverage yang rendah. Berbeda dengan dua penelitian tersebut, Nastiti dan Gumanti (2011) menunjukkan tingkat leverage berhubungan negatif tetapi tidak signifikan dengan manajemen laba. Berdasarkan penelitian terdahulu mengenai variabel leverage maka dapat dinyatakan hipotesis penelitian ketiga yaitu leverage berpengaruh negatif terhadap manajemen laba pada perusahaan sektor aneka industri yang melakukan IPO di BEI.

Dalam penelitian ini terdapat variabel independen baru yaitu tujuan penggunaan dana IPO. Tujuan penggunaan dana IPO dapat dijadikan variabel dalam menentukan manajemen laba karena keinginan perusahaan untuk mendapatkan nilai positif dari pasar dapat menjadi insentif bagi manajer untuk menyusun prospektus yang menarik dan laporan keuangan yang menarik, hal ini tidak menutup kemungkinan akan adanya praktik manajemen laba dalam penggunaan dana IPO, maka dapat dinyatakan hipotesis keempat yaitu tujuan penggunaan dana IPO berpengaruh negatif terhadap manajemen laba pada perusahaan sektor aneka industri yang melakukan IPO di BEI.

\section{Pengaruh Arus Kas Operasi terhadap Manajemen Laba}

Berdasarkan Pernyataan Standar Akuntansi Keuangan No. 2 (PSAK 2007: 2. 3) No. 2 Jumlah arus kas yang berasal dari aktivitas operasi merupakan acuan untuk menentukan apakah dari kegiatan operasi perusahaan dapat menghasilkan arus kas yang cukup untuk melunasi kewajiban, memelihara kemampuan operasi perusahaan, membayar deviden dan melakukan investasi baru tanpa mengandalkan sumber pendanaan dari luar. Jumlah arus kas ini dapat menggambarkan bagaimana perusahaan menggunakan serta menghasilkan kas dalam setiap kegiatan perusahaannya. Apabila kas bersih yang disediakan aktivitas operasi tinggi, maka ini menggambarkan bahwa perusahaan mampu menghasilkan kas yang mencukupi kebutuhan perusahaan dari operasi untuk membayar kewajibannya. Sebaliknya, apabila jumlah arus kas bersih yang dihasilkan oleh aktivitas operasi rendah, maka hal ini menggambarkan bahwa perusahaan tidak mampu menghasilkan kas yang cukup untuk memenuhi kebutuhan operasi perusahaannya.

Informasi mengenai arus kas dari aktivitas operasi dapat menjadi sinyal bagi investor untuk mengetahui kondisi perusahaan. Arus kas dari kegiatan operasi ini mencerminkan kondisi keuangan yang sebenarnya dan sulit dimanipulasi menggunakan pendekatan akuntansi manapun. Hamzah (2009) telah melakukan kajian tentang hubungan arus kas operasi dengan manajemen laba, hasil penelitian tersebut menunjukkan bahwa komponen arus kas operasi tidak mempunyai pengaruh terhadap manajemen laba. Mengacu pada alasan tersebut, hipotesis pertama dapat dirumuskan sebagai berikut:

$\mathrm{H}_{1}$ : arus kas operasi berpengaruh negatif terhadap manajemen laba pada perusahaan sektor aneka industri yang melakukan IPO di Bursa Efek Indonesia.

\section{Pengaruh Perubahan Laba terhadap Manajemen Laba}

FASB (Financial Accounting Standards Board) menyatakan bahwa indikator terbaik atas kinerja adalah laba. Jadi, memahami laba apa yang diukur oleh laba dan komponenkomponennya adalah penting untuk dapat memahami dan menginterpretasikan keadaan keuangan suatu perusahaan. Burgtahler and Dichev (1997) meneliti perusahaan di Amerika Serikat dan menyimpulkan bahwa manajer berusaha menghindari penurunan laba dan menghindari kerugian dengan melakukan manajemen laba. Nastiti dan Gumanti (2011) menganalisis hubungan antara perubahan laba dan manajemen laba, hasil penelitian tersebut 
menunjukkan perubahan laba berhubungan positif tetapi tidak signifikan dengan praktik manajemen laba. Oleh sebab itu, perubahan laba dapat dijadikan sebagai salah satu indikasi terjadinya manajemen laba. Berdasarkan alasan tersebut, dapat dirumuskan hipotesis kedua sebagai berikut:

$\mathrm{H}_{2}$ : perubahan laba berpengaruh positif terhadap manajemen laba pada perusahaan sektor aneka industri yang melakukan IPO di Bursa Efek Indonesia.

\section{Pengaruh Leverage terhadap Manajemen Laba}

Leverage menunjukkan proporsi penggunaan utang untuk membiayai investasinya. Semakin besar utang perusahaan semakin besar pula risiko yang dihadapi investor sehingga investor akan meminta tingkat keuntungan yang semakin tinggi. Tingkat leverage menunjukkan sejauh mana perusahaan dibiayai oleh pihak luar, bisa dikatakan bahwa leverage menunjukkan proporsi atas penggunaan utang untuk membiayai investasi perusahaan. Oleh karena itu, perusahaan harus memiliki kinerja yang baik dan laba yang tiggi untuk menarik calon investor. Hal ini sesuai dengan hipotesis dalam perjanjian utang yang menyatakan bahwa manajer termotifasi melakukan manajemn laba untuk menghindari pelanggaran perjanjian utang.

Widyaningdiah (2001) menganalisis hubungan antara leverage dan manajemen laba, hasil penelitian tersebut menunjukkan leverage berpengaruh signifikan terhadap manajemen laba. Berdasarkan alasan tersebut maka hipotesis yang diajukan adalah sebagai berikut:

$\mathrm{H}_{3}$ : leverage berpengaruh negatif terhadap manajemen laba pada perusahaan sektor aneka industri yang melakukan IPO di Bursa Efek Indonesia.

\section{Pengaruh Tujuan Penggunaan Dana IPO terhadap Manajemen Laba}

Tujuan penggunaan dana diukur dengan melihat besarnya persentase dana IPO yang digunakan untuk tujuan investasi dibandingkan dengan dana IPO keseluruhan. Investor pada umumnya lebih berminat pada perusahaan dengan tujuan penggunaan dana IPO untuk investasi. Kim et al. (1993) menyatakan bahwa dana dari IPO yang digunakan perusahaan untuk investasi mengisyaratkan pada investor jika perusahaan tersebut akan semakin berkembang dimasa yang akan datang dengan tujuan investasi yang jelas, dibandingkan dengan emiten yang akan menggunakan dana hasil IPOnya untuk membayar utang. Perusahaan yang menggunakan sebagian dana hasil IPO untuk keperluan investasi dapat dianggap memiliki kualitas yang baik karena dapat meningkatkan nilai perusahaan dan risiko yang dihadapi adalah rendah.

Tujuan penggunaan dana IPO dapat dijadikan variabel dalam menentukan manajemen laba karena keinginan perusahaan untuk mendapatkan nilai positif dari pasar dapat menjadi insentif bagi manajer untuk menyusun prospektus yang menarik dan laporan keuangan yang menarik, hal ini tidak menutup kemungkinan akan adanya praktik manajemen laba dalam penggunaan dana IPO. Berdasarkan alasan tersebut, dirumuskan hipotesis keempat sebagai berikut:

$\mathrm{H}_{4}$ : tujuan penggunaan dana IPO berpengaruh negatif terhadap manajemen laba pada perusahaan sektor aneka industri yang melakukan IPO di BEI.

\section{METODE PENELITIAN}

\section{Populasi dan Sampel}

Populasi dalam penelitian ini adalah semua perusahaan sektor aneka industri sebanyak 33 perusahaan, yang melakukan IPO pada tahun 1990 sampai tahun 2012. Sampel yang digunakan dalam penelitian ini didapat dengan menggunakan metode purposive sampling, yaitu penentuan sampel berdasarkan kriteria yang telah ditentukan. Kriteria pemilihan sampel yang digunakan dalam penelitian ini adalah perusahaan yang memiliki prospektus perusahaan yang tersedia di database Fakultas Ekonomi Universitas Jember, perusahaan yang mempunyai laporan keuangan minimal 3 tahun penuh dalam prospektus selama periode 19902012 karena untuk estimasi total akrual dibutuhkan data tiga tahun dan perusahaan memiliki nilai ekuitas positif karena jika ekuitas negatif akan mengakibatkan leverage yang merupakan salah satu variabel independen menjadi negatif dan DER negatif mengidikasikan kinerja yang buruk. 
Tabel 1: Gambaran Umum Sampel Penelitian Berdasarkan Tahun dan Sub Sektor Industri

\begin{tabular}{|c|c|c|c|c|c|c|c|c|c|c|c|c|c|}
\hline \multirow{2}{*}{ NO } & \multirow{2}{*}{ Sub sektor } & \multicolumn{7}{|c|}{ TAHUN } & \multirow[b]{2}{*}{ '05 } & \multirow[b]{2}{*}{ '07 } & \multirow[b]{2}{*}{ '11 } & \multirow[b]{2}{*}{$' 12$} & \multirow{2}{*}{$\Sigma$} \\
\hline & & 90 & 692 & 63 & 694 & .96 & 697 & '98 & & & & & \\
\hline 1 & Otomotif dan Komponen & 2 & - & 1 & - & 1 & - & 1 & 1 & - & - & - & 6 \\
\hline 2 & Tekstil dan Garment & 1 & 1 & 1 & - & - & 1 & 1 & - & - & 1 & 1 & 7 \\
\hline 3 & Kabel & - & 2 & - & - & - & - & - & - & - & - & - & 2 \\
\hline 4 & Alas Kaki & - & - & - & - & - & - & 1 & - & - & - & - & 1 \\
\hline \multirow[t]{2}{*}{5} & Elektronika & - & - & - & - & - & - & - & - & 1 & - & - & 1 \\
\hline & JUMLAH & 3 & 3 & 2 & $\mathbf{0}$ & 1 & 1 & 3 & 1 & 1 & 1 & 1 & 17 \\
\hline
\end{tabular}

Sampel yang digunakan dalam penelitian ini adalah perusahaan sektor aneka industri yang melakukan IPO dan memiliki kriteria dalam pengambilan sampel berdasarkan metode purposive sampling sebanyak 17 perusahaan atau $51,5 \%$ dari jumlah populasi.

Tabel 1 menunjukkan pengklasifikasian perusahaan sektor aneka industri yang melakukan IPO berdasarkan tahun dan sub sektor industrinya. Pada Tabel 1 terlihat bahwa jumlah sampel perusahaan yang melakukan IPO ditahun 1990, 1992, dan 1998 yaitu masing-masing sebanyak 3 perusahaan, tahun 1993 perusahaan sektor aneka industri yang melakukan IPO sebanyak 2 perusahaan, sedangkan tahun 1996, 1997, 2005, 2007, 2011, dan 2012 jumlah sampel hanya 1 perusahaan. Sampel Perusahaan sektor aneka industri yang melakukan IPO pada periode 1990-2012 paling banyak berada pada sub sektor tekstil dan garment yaitu sebanyak 7 perusahaan, peringkat kedua terbanyak berada pada sub sektor otomotif dan komponen sebanyak 6 perusahaan, selanjutnya diikuti oleh sub sektor kabel sebanyak 2 perusahaan, dan yang terakhir sampel dari sub sektor alas alas kaki dan elektronika masing-masing sebnyak 1 perusahaan.

\section{Variabel Penelitian dan Metode Analisis}

Variabel dependen penelitian ini adalah tingkat manajemen laba yang diukur dengan menggunakan Discretionary Accruals dengan mengacu pada model Friedlan (1994). Model Friedlan diukur menggunakan rumus sebagai berikut:

$$
\mathrm{DAC}_{p t}=\left(\mathrm{TAC}_{p t} / \mathrm{SALE}_{p t}\right)-\left(\mathrm{TAC}_{p d} / \mathrm{SALE}_{p d}\right)
$$

dimana $\mathrm{DAC}_{p t}$ adalah discretionary accruals pada periode tes, $\mathrm{TAC}_{p t}$ adalah total accruals pada periode tes, $\mathrm{TAC}_{p d}$ adalah total accruals pada periode dasar, adalah SALE $_{p t}$ adalah penjualan pada periode tes, $\mathrm{SALE}_{p d}$ adalah penjualan pada periode dasar, dan TAC adalah net income minus cash flow from operation.

Variabel bebas yang digunakan dalam penelitian ini ada empat, yaitu arus kas operasi, perubahan laba, leverage, dan penggunaan dana perusahaan. Arus kas operasi pada penelitian ini menggunakan perhitungan dengan variabel dummy yaitu, Skor 1 diberikan jika arus kas operasi penelitian (tahun $t$ ) lebih besar dari pada arus kas operasi tahun sebelumnya dan skor 0 apabila arus kas operasi tahun $t$ lebih kecil dari tahun sebelumnya.

Perubahan laba pada penelitian ini diukur dengan menggunakan variabel dummy, dimana skor 1 diberikan apabila laba tahun penelitian (tahun $t$ ) lebih besar dari pada tahun sebelumnya dan skor 0, apabila tidak (Chen et al., 2005). Leverage pada penelitian ini dapat diukur menggunakan rasio Total Debt to Equity Ratio (DER), yaitu membagi total utang dengan ekuitas pemegang saham. Tujuan penggunaan dana IPO diukur dengan menggunakan variabel dummy, yaitu jika dana perusahaan > 50\% digunakan untuk investasi maka mempunyai skor 1, selain itu maka diberi skor 0. Jika Investasi > 50\% dana dari IPO digunakan perusahaan diberi skor 1 .

Analisis data yang digunakan dalam penelitian ini adalah analisis regresi linier berganda. Analisis regresi merupakan salah satu teknik analisis data dalam statistika yang seringkali digunakan untuk mengkaji hubungan antara beberapa variabel dan meramal suatu variabel (Kutner et al., 2004). Analisis regresi linear berganda digunakan untuk mengukur pengaruh antara lebih dari satu variabel prediktor variabel bebas (X) terhadap variabel terikat (Y). Persamaan regresi berganda dalam penelith ini adalah sebaga $i$ berikut. 
$\mathrm{Y}=\mathrm{a}+\mathrm{b}_{1} \mathrm{X}_{1}+\mathrm{b}_{2} \mathrm{X}_{2}+\mathrm{b}_{3} \mathrm{X}_{3}+\mathrm{b}_{4} \mathrm{X}_{4}+\mathrm{e}$

dimana $(\mathrm{Y})$ merupakan proksi Manajemen Laba, $\left(\mathrm{X}_{1}\right)$ Arus Kas Operasi, $\left(\mathrm{X}_{2}\right)$ Perubahan Laba, $\left(\mathrm{X}_{3}\right)$ Rasio Leverage, $\left(\mathrm{X}_{4}\right)$ Penggunaan Dana Perusahaan, (a) Konstanta, $\left(\mathrm{b}_{1 . .4}\right)$ Koefisien regresi, dan (e) error.

\section{HASIL ANALISIS}

\section{Statistik Deskriptif Variabel-variabel Penelitian}

Variabel dependen yang digunakan dalam penelitian ini adalah manajemen laba. Manajemen laba dihitung dengan skala rasio yaitu menggunakan model Friedlan dengan menselisihkan antara total accrual yang distandarisasi dengan penjualan pada dua tahun yang berurutan. Variabel independen dalam penelitian ini adalah arus kas operasi, perubahan laba, tujuan penggunaan dana IPO yang dihitung dengan menggunakan variabel dummy dan leverage dihitung dengan menggunakan skala rasio. Tabel 2 menyajikan statistik deskriptif untuk variabel manajemen laba dan leverage.

Pada Tabel 2, dapat dilihat bahwa ratarata Discretionary Accrual (DAC) yang mencerminkan manajemen laba pada perusahaan sektor aneka industri yang melakukan IPO bernilai $-1,979 \%$. Nilai DAC yang negatif mengisyaratkan bahwa tidak ada indikasi bahwa manajemen telah melakukan upaya untuk menaikkan keuntungan melalui incomeincreasing discretionary accrual. Nilai DAC positif yang tertinggi terjadi pada PT. Jembo Cable Company Tbk., yaitu sebesar 0,290\% dan nilai DAC negatif tertinggi tertinggi terjadi pada PT. Multistrada Arah Sarana Tbk., yaitu sebesar $-30,375 \%$ yang go public pada tahun 2005.

Pada periode 1990 sampai dengan 2012 perusahaan yang melakukan IPO memiliki (LEV) leverage rata-rata sebesar $1,819 \%$ yang berarti rata-rata perusahaan pada sektor aneka industri mempunyai total utang yang digunakan sebagai pengungkit dalam rangka memak- simalkan tujuan perusahaan lebih besar dibanding dengan total ekuitas perusahaan, jadi risiko dari beban tetap yang harus ditanggung perusahaan menjadi lebih besar. Leverage dalam penelitian ini memiliki deviasi standar sebesar $0,640 \%$ dengan leverage tertinggi yaitu sebesar 3,270\% dimiliki oleh PT. Jembo Cable Companny Tbk., dan tingkat leverage terendah diperoleh oleh PT. Star Petrochem Tbk., sebesar $0,673 \%$ yang go pubic pada tahun 2011.

Variabel independen arus kas operasi, perubahan laba, dan tujuan penggunaan dana IPO dalam penelitian ini diukur dengan menggunakan variabel dummy. Arus kas operasi perusahaan sektor aneka industri yang mengalami kenaikan dari tahun sebelumnya mempunyai skor 1 sebanyak 12 perusahaan dan arus kas operasi perusahaan yang tidak mengalami kenaikan diberi skor 0 sebanyak 5 perusahaan. Perubahan laba perusahaan sektor aneka industri yang mengalami kenaikan dari tahun sebelumnya mempunyai skor 1 sebanyak 15 perusahaan dan perubahan laba yang tidak mengalami kenaikan diberi sekor 0 sebanyak 2 perusahaan. Dalam penelitian ini variabel tujuan penggunaan dana IPO diukur menggunakan variabel dummy dimana jika dana IPO lebih besar dari 50\% digunakan untuk investasi maka diberi skor 1 sebanyak 9 perusahaan, selain itu jika dana IPO lebih kecil dari 50\% diberi skor 0 sebanyak 8 perusahaan.

Dalam penelitian ini, pengujian normalitas data menggunakan uji Saphiro-Wilk karena banyak data kurang dari 50. Uji normalitas dilakukan untuk mengetahui normal tidaknya distribusi data penelitian. Data dikatakan berdistribusi normal apabila memiliki nilai probabilitas lebih besar dari 0,05 dan data dikatakan tidak berdistribusi normal apabila memiliki nilai probabilitas lebih rendah dari 0,05 . Hasil uji normalitas data untuk sampel sebanyak 17 perusahaan dapat dilihat pada Tabel 3.

Tabel 2: Hasil Analisis Deskriptif Variabel-Variabel Penelitian ( $\mathrm{n}=17)$

\begin{tabular}{ccccc}
\hline Variabel & Min. & Maks. & Rata-rata & Deviasi Standar \\
\hline DAC & $-30,38$ & 0,290 & $-1,979$ & 7,344 \\
LEV & 0,670 & 3,270 & 1,819 & 0,640 \\
\hline
\end{tabular}

Keterangan:

DAC adalah discretionary accrual, dan Lev adalah financial leverage. 
Tabel 3: Uji Normalitas Data $(n=17)$

\begin{tabular}{llll}
\hline Variabel & T-Stat & Sig. & Keterangan \\
\hline DAC & 0,313 & 0,000 & Tidak normal \\
\hline Leverage & 0,961 & 0,650 & Normal \\
\hline
\end{tabular}

Keterangan:

DAC adalah discretionary acruas, dan Lev adalah financial leverage.

Tabel 4: Hasis Analisis Deskriptif Variabel-Variabel Penelitian ( $\mathrm{n}=15)$

\begin{tabular}{lcccl}
\hline \multicolumn{1}{c}{ Variabel } & Min. & Maks. & Rata-rata & Deviasi Standar \\
\hline DAC & $-0,390$ & 0,290 & $-0,050$ & $-0,197$ \\
LEV & 0,670 & 3,270 & 1,808 & 0,667 \\
\hline
\end{tabular}

Tampak pada Tabel 3 bahwa variabel dependen manajemen laba yang diproksi menggunakan (DAC) berdistribusi tidak normal, karena memiliki nilai signifikansi kurang dari 0,05 . Sebaliknya, leverage sebagai variabel independen memiliki distribusi normal. Hal ini dilihat dari nilai signifikansi variabel leverage yang diuji dengan SaphiroWilk Test memiliki nilai lebih besar dari 0,05 yaitu sebesar 0,650. Sedangkan variabel arus kas opersasi, perubahan laba, dan tujuan penggunaan dana IPO merupakan variabel dummy, sehingga tidak perlu diuji normalitas datanya.

Dari hasil uji normalitas terdapat variabel penelitian yang tidak berdistribusi normal yaitu variabel discretionary acruals $(D A C)$. Untuk melanjutkan tahapan penelitian selanjutnya dibutuhkan data yang berdistribusi normal. Agar data berdistribusi normal terdapat beberapa cara yang digunakan, yaitu dengan transformasi LOG, LN, dan membuang data outlier. Dalam penelitian ini tranformasi LOG dan LN tidak mungkin untuk dilakukan karena terdapat data variabel yang bernilai 0 dan negatif, sehingga cara yang mungkin dilakukan adalah membuang data outlier. Data yang outlier pada penelitian ini terdapat pada nilai Discretionary Accruals (DAC) di dua perusahaan, yaitu PT. Multistrada Arah Sarana Tbk., yaitu sebesar $-30,375 \%$ dan PT. Sat Nusapersada Tbk., sebesar $-2,522 \%$ sehingga sampel pada penelitian ini menjadi sebanyak 15 perusahaan.

Hasil analisis deskriptif variabelvariabel penelitian untuk sampel sebanyak 15 perusahaan dapat dilihat pada Tabel 4. Ratarata Discretionary Accruals (DAC) yang mencerminkan manajemen laba pada per- usahaan sektor aneka industri dan bernilai $0,050 \%$. Nilai DAC negatif mengisyaratkan bahwa tidak ada indikasi bahwa manajemen telah melakukan upaya untuk menaikkan keuntungan melalui income-increasing discretionary accrual. Nilai DAC positif yang tertinggi ditemukan pada PT. Jembo Cable Company Tbk., yaitu sebesar 0,290\% dan nilai DAC negatif tertinggi terjadi pada PT. Indomobil Sukses Internasional Tbk., yaitu sebesar -0,393\% yang go public pada tahun 1993.

Pada periode 1990-2012 perusahaan yang melakukan IPO memiliki leverage ratarata sebesar $1,808 \%$ yang berarti rata-rata perusahaan pada sektor aneka industri mempunyai total utang yang digunakan sebagai pengungkit dalam rangka memaksimalkan tujuan perusahaan lebih besar dibanding dengan total ekuitas perusahaan, jadi risiko dari beban tetap yang harus ditanggung perusahaan menjadi lebih besar. Leverage dalam penelitian ini memiliki deviasi standar sebesar $0,667 \%$ dengan leverage tertinggi yaitu sebesar 3,270\% dimiliki oleh PT. Jembo Cable Companny Tbk., dan tingkat leverage terendah diperoleh oleh PT. Star Petrochem Tbk., sebesar 0,673 yang go pubic pada tahun 2011.

Arus kas operasi perusahaan sektor aneka industri yang mengalami kenaikan dari tahun sebelumnya mempunyai skor 1 sebanyak 10 perusahaan dan arus kas operasi perusahaan yang tidak mengalami kenaikan diberi skor 0 sebanyak 5 perusahaan. Perubahan laba perusahaan sektor aneka industri yang mengalami kenaikan dari tahun sebelumnya mempunyai skor 1 dan ditemukan sebanyak 12 perusahaan dan perubahan laba yang tidak mengalami kenaikan diberi sekor 0 dan ditemukan sebanyak 3 perusahaan. 
Tabel 5: Hasil Uji Normalitas Data $(\mathrm{n}=15)$

\begin{tabular}{cccc}
\hline Variabel & Statistic & Sig. & Keterangan \\
\hline DAC & 0,968 & 0,832 & Normal \\
Leverage & 0,967 & 0,804 & Normal \\
\hline
\end{tabular}

Dalam penelitian ini variabel tujuan penggunaan dana IPO diukur menggunakan variabel dummy dimana jika dana IPO lebih besar dari 50\% digunakan untuk investasi maka diberi skor 1 sebanyak 8 perusahaan, selain itu jika dana IPO lebih kecil dari 50\% diberi skor 0 sebanyak 7 perusahaan. Hasil uji normalitas data untuk sampel sebanyak 15 perusahaan dapat dilihat pada Tabel 5.

Variabel dependen manajemen laba yang diproksi menggunakan (DAC) dan leverage sebagai variabel independen berdistribusi normal, hal ini dikarenakan manajemen laba dan leverage memiliki nilai signifikansi lebih besar dari 0,05 . Nilai signifikansi variabel manajemen laba sebesar 0,832 yang berarti lebih besar dari 0,05 dan untuk variabel leverage nilai signifikasi yang diperoleh lebih besar dari 0,05 yaitu 0,804. Variabel independen yang terdiri atas arus kas opersasi, perubahan laba, dan tujuan penggunaan dana IPO merupakan variabel dummy, sehingga tidak perlu diuji normalitas datanya.

\section{Korelasi Parsial}

Korelasi parsial digunakan untuk mengetahui hubungan variabel-variabel independen dengan variabel dependen. Tabel 6 menyajikan matriks hasil uji korelasi parsial atas variabel-variabel penelitian.

Pada Tabel 6, dapat dilihat bahwa dari empat variabel yang diteliti hanya arus kas operasi yang berpengaruh negatif dan signifilan terhadap Discretionary Acrual. Sementara, perubahan laba (negatif), leverage (negatif), dan tujuan penggunaan dana IPO (negatif) tidak berkorelasi signifikan terhadap Discretionary Acrual. Sedangkan perubahan laba (positif), leverage (positif), tujuan penggunaan dana IPO (positif) tidak berkorelasi signifikan terhadap arus kas operasi. Leverage (positif) tidak berkorelasi signifikan dengan perubahan laba, tujuan penggunaan dana IPO berkorelasi positif dan signifikan dengan perubahan laba, dan yang terakhir tujuan penggunaan dana IPO berkorelasi negatif dan signifikan dengan leverage.

\section{Hasil Uji Regresi Linier Berganda}

Analisis regresi linear berganda digunakan untuk menguji pengaruh antara lebih dari satu variabel independen $(\mathrm{X})$ terhadap variabel dependen (Y). Hasil analisis regresi linier berganda dapat dilihat pada Tabel 7 .

Tabel 6: Hasil Korelasi Parsial ( $\mathrm{N}=15)$

\begin{tabular}{lcccc}
\hline & AKO & LBA & LEV & TPDI \\
\hline DAC & $-0,717^{* *}$ & $-0,064$ & $-0,025$ & $-0,274$ \\
AKO & & 0,000 & 0,067 & 0,189 \\
LBA & & & 0,080 & $0,535^{* *}$ \\
LEV & & & & $0,399^{*}$ \\
\hline
\end{tabular}

Keterangan:

DAC $=$ Discretionary Acruals, AKO = Arus Kas Operasi, LBA = Perubahan Laba, LEV

Leverage, TPDI = Tujuan Penggunaan Dana IPO. $* *=$ Signifikan pada 0,05 , *= Signifikan pada 0,10 .

Tabel 7: Hasil Analisis Regresi Linier Berganda

\begin{tabular}{cccccc}
\hline Variabel & Prediksi & Koef. & t-stat & Sig. & F-Stat (Sig) \\
\hline AKO & Negatif & $-0,67$ & $-2,98$ & 0,001 & 2,892 \\
LBA & Positif & 0,04 & 0,15 & 0,410 & $(0,079)$ \\
LEV & Negatif & $-0,06$ & $-0,23$ & 0,465 & $\mathrm{R}^{2}=0,536$ \\
TPDI & Negatif & $-0,19$ & $-0,62$ & 0,161 & Adj. $^{2}=0,351$ \\
\hline
\end{tabular}

Keterangan:

$\mathrm{AKO}=$ Arus Kas Operasi, LBA $=$ Perubahan Laba, LEV $=$ Leverage, TPDI $=$ Tujuan

Penggunaan Dana IPO 
Model regresi yang dihasilkan adalah sebagai berikut:

$\mathrm{Y}=0,187-0,273 X_{1}+0,021 X_{2}-0,018 X_{3}-0,075 X_{4}$

Pada model regresi di atas, dapat dilihat bagaimana pengaruh variabel arus kas operasi, perubahan laba, leverage dan tujuan penggunaan dana IPO terhadap manajemen laba. Jika berpengaruh positif menandakan bahwa manajemen laba (DAC) akan berubah searah dengan variabel bebasnya, sebaliknya jika berpengaruh negatif, maka perubahan manajemen laba menuju arah yang berlawanan dengan perubahan variabel bebasnya. Setelah melakukan uji analisis regresi linier berganda, variabel dalam model regresi diuji menggunakan uji asumsi klasik, sehingga didapat bahwa variabel pada model regresi terbebas dari multikolinieritas, dan heteroskedastisitas.

Variabel arus kas operasi memiliki nilai koefisien sebesar $-0,273$ dan nilai $\mathrm{p}=0,001$, yang berarti lebih rendah daripada $\alpha=0,05$, sehingga $\mathrm{H}_{0}$ ditolak. Artinya, arus kas operasi berpengaruh negatif terhadap manajemen laba pada perusahaan sektor aneka industri yang melakukan IPO di BEI.

Nilai koefisien perubahan laba sebesar 0,021 dan nilai $p=0,410$, yang berarti lebih besar daripada $\alpha=0,05$, sehingga $\mathrm{H}_{0}$ diterima. Artinya, perubahan laba tidak berpengaruh signifikan terhadap manajemen laba pada perusahaan sektor aneka industri yang melakukan IPO di BEI.

Leverage memiliki nilai koefisien sebesar $-0,018$ dan memiliki nilai $\mathrm{p}=0,465$, yang berarti lebih besar daripada $\alpha=0,05$, sehingga $\mathrm{H}_{0}$ diterima. Artinya, leverage tidak berpengaruh signifikan terhadap manajemen laba pada perusahaan sektor aneka industri yang melakukan IPO di BEI.

Tujuan penggunaan dana IPO memiliki nilai koefisien sebesar $-0,075$ dan nilai $\mathrm{p}=$ 0,161 , yang berarti lebih besar daripada $\alpha=$ 0,05, sehingga $\mathrm{H}_{0}$ diterima. Artinya, tujuan penggunaan dana IPO tidak berpengaruh signifikan terhadap manajemen laba pada perusahaan sektor aneka industri yang melakukan IPO di BEI.

\section{PEMBAHASAN}

Penelitian ini menemukan bahwa arus kas operasi berpengaruh negatif dan signifikan terhadap manajemen laba pada perusahaan sektor aneka industri yang melakukan IPO di BEI tahun 1990-2012. Hal ini menunjukkan bahwa setiap penurunan arus kas operasi mampu menyebabkan kenaikan manajemen laba. Jika arus kas operasi meningkat maka manajemen laba akan mengalami penurunan. Rata-rata nilai DAC perusahaan yang mengalami penurunan arus kas operasi adalah sebesar 0,143 sedangkan perusahaan yang mengalami kenaikan arus kas operasi adalah sebesar -0,147. Hal ini menunjukkan bahwa peningkatan arus kas operasi akan menyebabkan penurunan DAC dan penurunan arus kas operasi akan menyebabkan kenaikan DAC. Jika arus kas operasi perusahaan bagus, perusahaan akan cenderung menurunkan tingkat manajemen laba karena untuk menunjukkan bahwa perusahaan mampu dalam menghasilkan laba. Sebaliknya jika arus kas operasi perusahaan menurun, perusahaan akan cenderung menaikkan tingkat manajemen laba karena perusahaan tidak mampu membiayai kegiatan operasional. Dengan demikian perusahaan terdorong untuk melakukan manajemen laba. Hasil penelitian ini mendukung penelitian yang dilakukan oleh Nastiti dan Gumanti (2011) yaitu, arus kas operasi berhubungan negatif dan signifikan dengan manajemen laba.

Arus kas dari aktivitas operasi mencerminkan kondisi rill keuangan yang diterima atau dikeluarkan perusahaan. Arus kas operasi sulit untuk dimanipulasi bahkan menggunakan pendekatan akuntansi apapun, namun pada penelitian ini ditemukan bahwa arus kas operasi mengindikasikan manajemen laba yang dilakukan oleh perusahaan sektor aneka industri. Hasil penelitian ini sesuai dengan yang diharapkan dimana arus kas operasi memiliki hubungan yang negatif terhadap manajemen laba, yang berarti besar kecilnya arus kas operasi akan menjadi dasar manajemen untuk melakukan manajemen laba sebelum IPO, dimana jika AKO meningkat maka manajemen laba cenderung menurun.

Perubahan laba berpengaruh negatif tetapi tidak signifikan terhadap praktik manajemen laba pada perusahaan sektor aneka industri yang melakukan IPO tahun 1990 sampai 2012. Hal ini menunjukkan bahwa setiap kecenderungan penurunan perubahan laba tidak mampu menyebabkan kenaikan manajemen laba. Hal tersebut mendukung 
penelitian yang dilakukan oleh Nastiti dan Gumanti (2011) yang menyatakan bahwa perubahan laba berhubungan positif tetapi tidak signifikan dengan praktik manajemen laba. Namun, penelitian ini berbeda dengan penelitian yang dilakukan oleh Burgstahler and Dicev (1997) di pasar modal Amerika Serikat, yang menyimpulkan bahwa manajer berusaha menghindari penurunan laba dan menghindari kerugian dengan melakukan earnings management.

Hasil yang diperoleh dari penelitian ini tidak sesuai dengan yang diharapkan, dimana kenaikan atau penurunan laba perusahaan pada tahun $t$ dibandingkan dengan tahun sebelumnya $(t-1)$ tidak memengaruhi praktik manajemen laba. Bukti empiris dalam penelitian ini menyiratkan bahwa setiap kenaikan perubahan laba tidak diikuti oleh penurunan manajemen laba, tetapi karena koefisien tidak signifikan maka kenaikan dan penurunan tidak menyebabkan perusahaan melakukan manajemen laba sebelum IPO. Perusahaan yang perubahan labanya mengalami kenaikan memiliki rata-rata DAC sebesar $-0,053$, sedangkan perusahaan yang perubahan labanya mengalami penurunan memiliki rata-rata DAC sebesar $-0,031$. Hal ini menunjukkan bahwa baik perusahan yang mengalami penurunan maupun kenaikan laba memiliki rata-rata DAC yang relatif sama, sehingga wajar jika perubahan laba tidak berpengaruh terhadap manajemen. Hal ini diperkuat dengan korelasi parsial antara perubahan laba yang berkorelasi negatif tidak signifikan terhadap DAC.

Leverage ditemukan berpengaruh positif tetapi tidak signifikan terhadap praktik manajemen laba pada perusahaan sektor aneka industri yang melakukan IPO periode 1990 sampai 2012. Hal ini menunjukkan bahwa setiap peningkatan leverage tidak mampu menyebabkan penurunan manajemen laba. Penelitian ini mendukung penelitian Nastiti dan Gumanti (2011) yang menyatakan tingkat leverage berhubungan negatif tetapi tidak signifikan dengan praktik manajemen laba. Namun, penelitian ini berbeda dengan penelitian DeFond and Jiambalvo (1994), Chen et al. (2005), dan Sanjaya (2008), yang membuktikan secara empiris bahwa perusahaan dengan tingkat leverage tinggi cenderung melakukan earnings management dibanding perusahaan dengan tingkat leverage yang kecil.
Leverage yang tinggi disebabkan oleh total utang perusahaan yang lebih besar dibandingkan ekuitas perusahaan. Hal tersebut menunjukkan bahwa rata-rata perusahaan di sektor aneka industri sebagian besar membiayai perusahaan dengan dana yang didapat dari utang, yang mengindikasikan perusahaan sektor aneka belum mampu menghasilkan dana dari sumber internal. Idealnya leverage yang tinggi akan mendorong perusahaan melakukan income increasing discretionary accruals. Dalam penelitian ini kondisi tersebut tidak terbukti, walaupun koefisiennya seperti yang diprediksi. Artinya, perusahaan aneka industri tidak menjadikan besaran leverage sebagai penentu praktik manajemen laba. Hal ini juga ditunjang oleh korelasi parsial leverage dengan manajemen laba yang relatif rendah, yaitu sebesar $-0,025$.

Tujuan penggunaan IPO ditemukan berpengaruh negatif tetapi tidak signifikan terhadap praktik manajemen laba pada perusahaan sektor aneka industri yang melakukan IPO tahun 1990 sampai 2012. Hal ini menunjukkan bahwa penggunaan dana IPO untuk investasi tidak mampu menyebabkan penurunan manajemen laba. Hasil dari penelitian ini tidak sesuai dengan yang diharapkan dimana tujuan penggunaan dana IPO berpengaruh terhadap terjadi praktik manajemen laba.

Pada perusahaan sektor aneka industri yang melakukan IPO pada periode 1990-2012, tujuan penggunaan dana IPO untuk investasi tidak memengaruhi terjadinya praktik manajemen laba. Hal ini dikarenakan perusahaan tidak termotivasi untuk melakukan manajemen laba, karena dana yang digunakan oleh perusahaan sektor aneka industri digunakan untuk melunasi utang dan modal kerja. Selain itu investor tidak melihat kualitas perusahaan dalam mengelola dana perusahaannya dari berapa persen dana untuk kegiatan investasi, akan tetapi calon investor lebih melihat pada kesuksesan persusahaan secara keseluruhan. Dengan demikian tujuan penggunaan dana IPO tidak dapat mengindikasikan adanya manajemen laba pada perusahaan sektor aneka industri pada saat IPO. Hal ini dapat dilihat dari perusahaan yang menggunakan dana IPOnya untuk investasi memiliki rata-rata DAC sebesar $-0,099$, sebaliknya perusahaan yang menggunakan dana IPOnya tidak untuk investasi 
memiliki rata-rata DAC sebesar 0,005. Artinya, perusahaan yang menggunakan dana IPO-nya untuk investasi, dan perusahaan yang tidak menggunakan dana IPOnya untuk investasi sama-sama memeliki kecenderungan untuk melakukan manajemen laba.

\section{PENUTUP}

Penelitian ini menguji pengaruh arus kas dari aktivitas operasi, perubahan laba, leverage, dan tujuan penggunaan dana terhadap manajemen laba pada perusahaan sektor aneka industri yang melakukan IPO di BEI pada periode 1990 sampai 2012. Hasil penelitian menunjukkan bahwa dari empat variabel ayng diteliti, hanya arus kas operasi berpengaruh negatif dan signifikan terhadap praktik manajemen laba. Sedangkan perubahan laba, leverage, dan tujuan penggunaan IPO tidak berpengaruh tingkat manajemen laba.

Ada beberapa keterbatasan yang teridentifikasi dalam penelitian ini. Pertama, model yang digunakan dalam perhitungan disscretionary current acruals dipilih tanpa pengujian terlebih dahulu sehingga belum tentu model perhitungan Friedlan (1994) ini dapat menentukan apakah cocok atau tidak dengan kondisi di Indonesia. Kedua, dalam penelitian ini leverage diukur sebagai rasio utang yang distrandarisasi dengan ekuitas sehingga memperoleh nilai yang sangat bervariasi. Pada penelitian sebelumnya, Nastiti dan Gumanti (2011) menghitung Leverage dengan menggunakan rasio total utang distandarisasi dengan total aset. Ketiga, perubahan laba dan tujuan penggunaan dana IPO dalam penelitian ini menggunakan proksi variabel dummy. Hasil penelitian bisa berbeda jika definisi operasional variabel tidak menggunakan basis dummy. Keempat, penelitian ini tidak mempertimbangkan keberadaan dewan komisaris independen sebagai penentu nilai IPO yang tentunya juga dapat memengaruhi motivasi manajemen untuk melakukan manajemen laba. Bertoni et al. (2014) menemukan di Perancis, Jerman dan Italia bahwa dewan komisaris mampu memengaruhi kualitas IPO. Terakhir, penelitian ini tidak menganalisis reputasi auditor sebagai pembatas manajemen laba. Di China, Chen et al. (2013) menemukan bahwa perusahaan milik negara yang melakukan IPO mengalami manajemen leba lebih rendah jika perusahaan dijamin oleh penjamin emisi berkualitas.

Berdasarkan kesimpulan dan keterbatasan penelitian, beberapa saran dapat diajukan. Pertama, penelitian selanjutnya dapat menggunakan model selain model Friedlan untuk menghitung DAC yang berbasis industri seperti yang dilakukan pada penelitian Nastiti dan Gumanti (2011). Kedua, proksi atas leverage dapat menggunakan rasio total debt to total assets, atau total long term debt to total asset . Penggunaan rasio perubahan laba dapat dilakukan dengan tidak berbasis dummy, dan tujuan dana IPO dapat dihitung dengan cara menggunakan persentase penggunan dana untuk investasi. Penelitian yang akan datang juga dapat memasukkan keberadaan dewan komisaris independen sebagai pembatas manajemen laba di IPO atau dengan memasukkan variabel kualitas atau reputasi penjamin emisi.

\section{DAFTAR PUSTAKA}

Aussenegg, W., P. Inwinkl, and G. Schneider, G. 2009. Earnings Management and Accounting Standards in Europe. Proceeding of the 2009 MFA Annual Meeting.

Bertoni, F., M. Meoli, and S. Vismara. 2014. Board Independence, Ownership Structure and the Valuation of IPOs in Continental Europe, Corporate Governance: An International Review, 22(2), 116-131.

Buck, G. C. 1990. Pricing Initial Public Offerings. Dalam Khun, R. (Editor), Capital Raising and Financial Structure. New York. Richard D Irwin.

Burgstahler D. and I. Dichev. 1997. Earnings Management to Avoid Earnings Decreases and Losses, Journal of Accounting and Economics, 24 (1), 99126.

Chen, K., K. Lin, and J. Zhou. 2005. Audit Quality and Earnings Management for Taiwan IPO Firms, Managerial Auditing Journal, 20 (1), 86-104.

Chen, C., H.Shi, and H. Xu. 2013. Underwriter Reputation, Issuer Ownership, and PreIPO Earnings Management: Evidence 
from China, Financial Management, Fall, 647-677.

DeFond, M. and M.J. Jimbalvo. 1994. Debt Covenant Violation and Manipulation of Accruals, Journal of Accounting and Economics, 17 (2), 145-176.

Friedlan, M.L. 1994. Accounting Choices of Issuers of Initial Public Offerings, Contemporary Accounting Research, $11(1), 1-31$.

Hamzah, A. 2009. Deteksi Earnings Management Melalui Baban Pajak Tangguhan, Akrual dan Arus Kas Operasi. Jurnal Manajemen Teori dan Terapan. 2 (3), 1-13.

Healy, P. and J. Wahlen. 1999. A Review of Earnings Management Literatures and Its Implication for Standard Setting, Accounting Horizon, 13 (4), 345-383.

Hsu, M.F. and S.Y.Wen. 2015. The Roles of Institutional Investors and Insiders in Earnings Management around Initial Public Offering Firms in Taiwan, International Journal of Economics and Financial Issues, 5 (2), 340-353.

Kim, K. B., I. Krisky. and J. Lee. 1993. Motives for Going Public and Underpricing: New Findings from Korea, Journal of Business Finance and Accounting, 20 (2), 195-211.

Kutner, M.H., C.J., Nachtsheim, and J. Neter. 2004. Applied Linear Regression Models. $4^{\text {th }}$ ed. New York: McGrawHill Companies, Inc.
Nastiti, A. S. dan T.A. Gumanti. 2011. Kualitas Audit dan Manajemen Laba pada Initial Public Offerings di Indonesia. Simposium Nasional Akuntansi (SNA) 14. Universitas Syah Kuala, Banda Aceh.

Niagara M. N., dan T.A. Gumanti. 2007. Akuntansi Kreatif dan Manajemen Laba: Suatu Telaah, Jurnal Akuntansi, 11 (1), 1-19.

Rahman, A. 2008. Manajemen Laba Melalui Akrual dan Aktivitas Real pada Penawaran Perdana dan Hubungannya dengan Kinerja Jangka Panjang (Studi Empiris pada BEJ), Jurnal Akuntansi dan Keuangan Indonesia, 5 (1), 1-29.

Sanjaya, I. P. 2008. Auditor Eksternal, Komite Audit, dan Earnings Management, Jurnal Riset Akuntansi Indonesia, 11(1), 97-116.

Scott, G. M. 1997. Financial Accounting Theory. New York. Prentice Hall International.

Surifah. 1999. Informasi Asimetri dan Pengaruh Manajamen terhadap Pelaporan Keuangan dalam Prespektif Agency Theory, Kajian Bisnis. 17 (Mei-Sept), 71-82.

Widyaningdyah, A. U. 2001. Analisis Faktorfaktor yang Berpengaruh Terhadap Earnings Management pada Perusahaan Go Public di Indonesia, Jurnal Akuntansi dan Keuangan, 3 (2), 89-101. 